\title{
On the influence of topographic, geological and cryospheric factors on rock avalanches and rockfalls in high-mountain areas
}

\author{
L. Fischer ${ }^{1, *}$, R. S. Purves ${ }^{1}$, C. Huggel ${ }^{1}$, J. Noetzli ${ }^{1}$, and W. Haeberli ${ }^{1}$ \\ ${ }^{1}$ Department of Geography, University of Zurich, Switzerland \\ *now at: Geological Survey of Norway (NGU), Trondheim, Norway
}

Correspondence to: L. Fischer (luzia.fischer@ngu.no)

Received: 24 April 2011 - Revised: 28 September 2011 - Accepted: 4 December 2011 - Published: 31 January 2012

\begin{abstract}
The ongoing debate about the effects of changes in the high-mountain cryosphere on rockfalls and rock avalanches suggests a need for more knowledge about characteristics and distribution of recent rock-slope instabilities. This paper investigates 56 sites with slope failures between 1900 and 2007 in the central European Alps with respect to their geological and topographical settings and zones of possible permafrost degradation and glacial recession. Analyses of the temporal distribution show an increase in frequency within the last decades. A large proportion of the slope failures $(60 \%)$ originated from a relatively small area above $3000 \mathrm{~m}$ a.s.l. (i.e. $10 \%$ of the entire investigation area). This increased proportion of detachment zones above $3000 \mathrm{~m}$ a.s.l. is postulated to be a result of a combination of factors, namely a larger proportion of high slope angles, high periglacial weathering due to recent glacier retreat (almost half of the slope failures having occurred in areas with recent deglaciation), and widespread permafrost occurrence. The lithological setting appears to influence volume rather than frequency of a slope failure. However, our analyses show that not only the changes in cryosphere, but also other factors which remain constant over long periods play an important role in slope failures.
\end{abstract}

\section{Introduction}

Slope failures on steep mountain flanks and resulting rock avalanches and rockfall are a major process in landscape evolution (Densmore and Hovius, 2000; Korup et al., 2005), but they also present a serious hazard in many mountain regions of the world (Eisbacher and Clague, 1984; Evans et al., 2002). Making statements about the likely locations and timing of such mass movement processes on bedrock slopes requires an understanding of the processes and factors relevant for local slope instabilities as well as of the spatial and temporal variability of theses factors. The distribution and characteristics of detachment zones, such as are recorded in inventories, can be used as proxy data for analyses of potential predisposing factors for slope failures (Carrara and Pike, 2008; van Westen et al., 2008; Allen et al., 2011). Thus, establishing relationships between present-day slope failures and hypothesised causal factors is one way of improving understanding of conditions under which instabilities develop. Such an improved understanding could help to differentiate between unfavourable settings which are essentially constant (e.g. those related to geology or elevation) and those which may develop dynamically over relatively short time periods (e.g. those related to cryospheric changes), and thus aid decision makers in the assessment of the susceptibility of locations to future events. A better understanding of the potential impact of ongoing climatic change on high mountain environments and related slope instabilities is increasingly important, not least because human settlements and activities have been progressively extended towards endangered zones in many mountain regions.

In this study, we analyzed the detachment zones of recorded rock avalanche and large rockfall events in the central European Alps since around 1900. In doing so, we explored the regional distribution of slope failures on steep periglacial rock walls and analysed the characteristics of detachment zones with respect to their geological and topographical distribution. In our study, we emphasize the spatial distribution of failures relative to zones of possible permafrost degradation and glacial recession using descriptive statistics. The major objectives of this study are thus:

1. to reconstruct the topographic, lithological and cryospheric setting at each detachment zone for recorded rock avalanche and large rockfall events in the Central European Alps since 1900;

2. to compare these particular settings with the overall spatial distribution of the related factors; and

3. to analyse the temporal distribution of the events. 

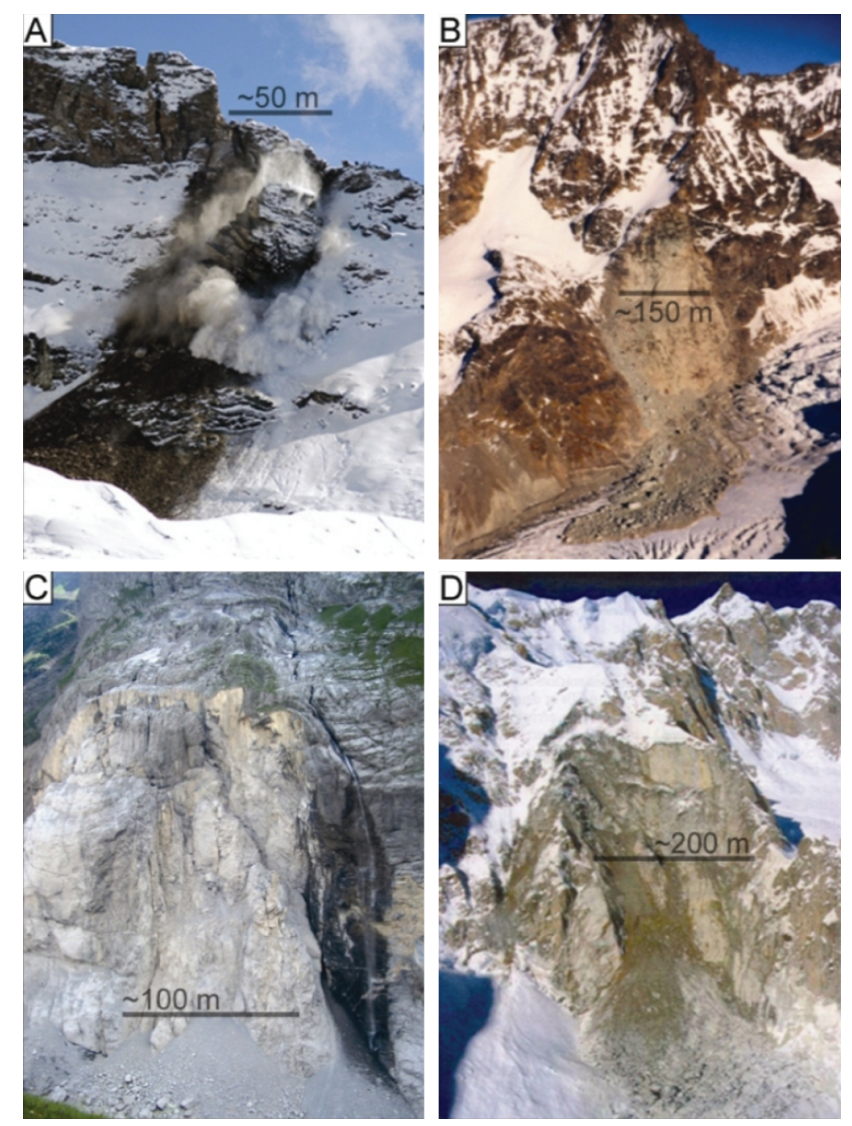

Fig. 1. Selected examples of detachment zones of recent large rockfall and rock avalanche events in the European Alps, ordered by their size. (A) Kärpf (CH), 2007, $2 \times 10^{4} \mathrm{~m}^{3}$ (O. Adolf), (B) Tschierva $(\mathrm{CH}) 1988,3 \times 10^{5} \mathrm{~m}^{3}$ (A. Amstutz), $(\mathbf{C})$ Eiger $(\mathrm{CH})$, 2006, $1 \times 10^{6} \mathrm{~m}^{3}$ (L. Fischer), (D) Brenva (I), 1997, $2 \times 10^{6} \mathrm{~m}^{3}$ (G. Mortara). Approximate scale bars indicate the size of the detachment zones.

\section{Background}

During recent decades, a number of extraordinary and catastrophic rock avalanche events with volumes between $10^{5}$ and $10^{7} \mathrm{~m}^{3}$, but also many more frequent small-volume rockfall events, have occurred worldwide in periglacial environments, and it has been conjectured that these may be related to ongoing and past changes in permafrost and glacierization. Corresponding events have been documented for different mountain belts including the European Alps (e.g. Barla et al., 2000; Deline, 2001; Noetzli et al., 2003; Crosta et al., 2004; Cola, 2005; Oppikofer et al., 2008; Fischer, 2009, Fig. 1), Canada and Alaska (e.g. Evans and Clague, 1994; Geertsema et al., 2006), the Caucasus (e.g. Haberli et al., 2004) and for New Zealand (e.g. Allen et al., 2011). Not only large-volume events have been observed, but also many smaller rockfalls have been observed, for example in the European Alps in the very warm summer of 2003 (e.g. Keller, 2003; Gruber et al., 2004; Ravanel and Deline, 2010).
Slope instability phenomena in high-mountain areas are related to a number of factors including topography, geological characteristics, hydrological setting, climatic factors, and cryospheric conditions (e.g. Ballantyne 2002; Evans et al., 2002). Changes in one or more of these may change slope stability and eventually lead to slope failure. Rock slope stability is primarily governed by rock-mass strength, geological structures, slope angle and slope height, which vary according to the geological and geomechanical settings. Geological factors may change over geological periods, but can be regarded as more or less stable for shorter periods. However, glaciers, permafrost and the hydrological setting can undergo both long-term and rapid changes due to their sensitivity to climatic changes. As a direct consequence of glacier retreat and ice surface lowering, previously ice-bonded rock walls become exposed, inducing changes in thermal and mechanical boundary conditions (Wegmann et al., 1998). This in turn induces changes in the stress field inside the bedrock to great depths (Augustinus, 1995; Fischer et al., 2010), while the retreat of temperate glaciers can enable the formation of permafrost (Wegmann et al., 1998; Kneisel, 2003). The penetration of a freezing front into previously thawed material has the potential to intensify rock destruction and such ice formation may reduce the near-surface permeability of the rock walls involved and potentially cause increased hydraulic pressures (Tart, 1996; Wegmann et al., 1998). Gruber and Haeberli (2007) argued that different physical processes may link warming permafrost to destabilisation of steep bedrock, such as the loss of ice bonding in fractures, reduction of shear strength and increased hydrostatic pressure. Laboratory studies have demonstrated that the shear strength of an ice-bonded rock discontinuity significantly reduces with warming (Davies et al., 2001). Furthermore, permafrost degradation through thermal advection by running water can rapidly lead to the development of deep thaw corridors along fracture zones and potentially destabilise much larger volumes of rock than conduction in similar timescales (Huggel, 2009; Hasler, 2011).

In studies based on landslide inventories, slope-failure susceptibility has been explored using both individual and combined causative factors (e.g. Baillifard et al., 2003; Ruff and Czurda, 2008; Allen et al., 2011). Comprehensive data compilation and analyses of rockfall and rock avalanche events in the Swiss and European Alps were undertaken by Abele (1974) and Gruner (2004). However, these studies did not consider cryospheric parameters, although some important linkages between surface and subsurface ice and rockslope failures have been proposed by other authors, for example, from the initial analysis of an inventory of recent rock avalanches in the European Alps (Noetzli et al., 2003), another inventory analysis in the Southern Alps of New Zealand (Allen et al., 2011), and detailed case studies of individual slope failures or groups of events (e.g. Fischer et al., 2006, Huggel, 2009; Fischer et al., 2010; Ravanel, 2010). Building upon the analysis of the inventory of rock-slope failures in 
the European Alps developed by Noetzli et al. (2003), this study will complement existing research through the analysis of a larger data set and integration of further factors, and specifically present an integrated discussion with respect to the influence of geology, glacial ice recession and permafrost warming on recent rock avalanche and large rockfall events in the central European Alps.

\section{Data and methodology}

We use a Geographical Information System (GIS) to perform a spatial analysis and generate descriptive statistics of possible causative factors (1) over the entire study area and (2) of the detachment zones of recent rock avalanche and large rockfall events. The primary data set is an inventory, which contains 56 sites where slope failure events occurred between 1900 and 2007 in the Swiss Alps and adjacent areas of France and Italy (Fig. 2, Table 1). The inventory is based on that developed by Noetzli (2003), which has since been updated continuously with information from other inventories (Kubat, 2007; Nägeli, 2010; PERMOS, 2010), scientific publications, newspaper articles, field observations, and personal communications. Additionally, inventories on prehistoric and historic rock avalanche events in the European Alps by Montandon (1933) and Abele (1974) were considered. The selection criteria were a detachment zone above $2000 \mathrm{~m}$ a.s.l., as this study focuses on a periglacial environment, and an estimated volume of more than $1000 \mathrm{~m}^{3}$.

For the analysis of topographic attributes, a digital elevation model with $25 \mathrm{~m}$ resolution (DHM25 Level 2; Swisstopo, 2004) was used. The geological setting of the study areas was derived from a digital geotechnical map (Swiss Geotechnical Commission), based on the Geotechnical Map of Switzerland (1:200 000). The geological units were simplified to six classes in order to allow investigations at a regional scale (Fig. 3). The glaciation history in the Swiss Alps since the Little Ice Age termination (about 1850) was described using an existing digital glacier inventory of the Swiss Alps, which contains glacier extents around 1850 from topographic maps (Maisch, 1992), in 1973 from aerial photography (Müller et al., 1976), and in 1998 from satellite images (Paul, 2004). Permafrost distribution was assessed using the PERMAKART model (Haeberli, 1975; Keller, 1992) and modelled $0{ }^{\circ} \mathrm{C}$-isotherm of near-surface temperatures in steep rock (Gruber et al., 2004), to indicate the lower permafrost boundaries. These separate data layers were spatially analysed over the entire area and specific factor sets were extracted for each detachment zone.

\section{Geographical setting}

The area covers $25000 \mathrm{~km}^{2}$ of the central European Alps, centred upon the Swiss Alps, but also extending west to the Mont Blanc area in the French Alps and including parts of

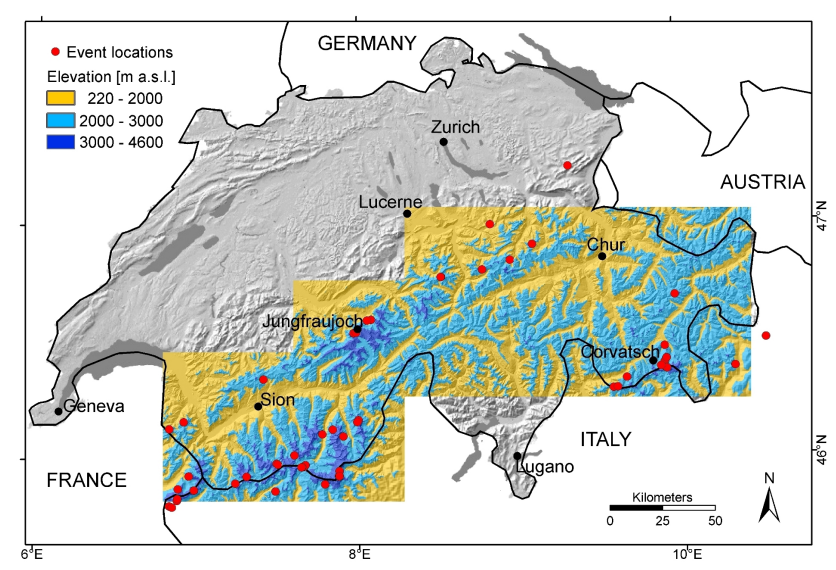

Fig. 2. Location of the recorded rockfall and rock avalanche events (red dots) and marked in blue the investigation area. The area below $2000 \mathrm{~m}$ a.s.l. is not included in the statistical analyses. DHM25 provided by swisstopo.

the Italian Alps (Figs. 2 and 3). Elevation ranges from 220 to more than $4600 \mathrm{~m}$ a.s.l. and includes the highest and most heavily glacierized areas of the European Alps. $50 \%$ of this area lies below $2000 \mathrm{~m}$ a.s.1., $45 \%$ between 2000 and $3000 \mathrm{~m}$, and only $5 \%$ is above $3000 \mathrm{~m}$ a.s.l. Within our study, only the areas above $2000 \mathrm{~m}$ a.s.l. are considered (Fig. 2).

The Alpine range consists of different main tectonic units, which can be divided from north to south into the Helvetic, Penninic, Eastern, and Southern Alpine (Fitzsimons and Veit, 2001). The Helvetic, forming the northern boundary of the Central Alps, consists mainly of limestones, shales and marls (Fig. 3). The Penninic has the highest metamorphic grade and is composed of large areas of gneiss from the crystalline basement and zones with ophiolite sequences and deep marine sediments, metamorphosed to phyllites, schists and amphibolites. The Eastern Alpine contains mainly schists, gneisses, dolomite and limestone that have only minor metamorphic overprint from the Alpine orogenesis. In addition, intrusions from different epochs exist as the four main massifs Aar Massif, Gotthard Massif, Aiguilles Rouges Massif and Mont Blanc Massif, which mainly consist of gneiss and granite.

Late Pleistocene glacial cycles and periglacial weathering carved and shaped the European Alps, resulting in the typical alpine relief with U-shaped valleys, hanging valleys, and steep peaks. During the Last Glacial Maximum (LGM, about $21000 \mathrm{yr}$ BP), glaciers covered most of the European Alps and surrounding area with an extent of about $150000 \mathrm{~km}^{2}$ (Keller and Krayss, 1998). Between the Little Ice Age (LIA) termination around 1850, with glacier extent around $4470 \mathrm{~km}^{2}$, and 2000, an overall glacier area loss of almost $50 \%$ occurred, with the glacier extent being reduced to around $2270 \mathrm{~km}^{2}$ (Zemp et al., 2006). Nowadays, the lower boundary of glacierization is at approximately $1600 \mathrm{~m}$ a.s.l. 
Table 1. Characteristics of the 56 sites with recorded rock avalanche and rockfall events.

\begin{tabular}{|c|c|c|c|c|c|c|c|}
\hline No & Name & Date & $\begin{array}{r}\text { X } \\
\text { coordinate }\end{array}$ & $\begin{array}{r}\mathrm{Y} \\
\text { coordinate }\end{array}$ & $\begin{array}{r}\text { Volume class } \\
\qquad\left(\mathrm{m}^{3}\right)\end{array}$ & $\begin{array}{r}\text { Mean } \\
\text { elevation }\end{array}$ & Aspect \\
\hline 1 & Fletschhorn & 19 March 1901 & 643140 & 113690 & $>10^{6}$ & 3630 & $\mathrm{NE}$ \\
\hline 2 & Kleiner Spannort I & 14 May 1905 & 682370 & 181680 & $10^{4}-10^{5}$ & 2980 & $\mathrm{~N}$ \\
\hline 3 & Brenva I & 14/19 November 1920 & 556690 & 75230 & $>10^{6}$ & 3950 & SE \\
\hline 4 & Felik & 4 August 1936 & 627270 & 83120 & $10^{5}-10^{6}$ & 3320 & SW \\
\hline 5 & Jungfrau & 6 October 1937 & 640800 & 154980 & $10^{5}-10^{6}$ & 3700 & SE \\
\hline 6 & Matterhorn & 9 July/18 August 1943 & 617260 & 91460 & $10^{5}-10^{6}$ & 3810 & $\mathrm{E}$ \\
\hline 7 & Miage I & spring 1945 & 552950 & 72600 & $10^{5}-10^{6}$ & 3050 & $\mathrm{NE}$ \\
\hline 8 & Six des eaux froides & 30 May 1946 & 597830 & 132920 & $>10^{6}$ & 2720 & S \\
\hline 9 & Drus I & 1950 & 562350 & 86880 & $10^{4}-10^{5}$ & 3250 & $\mathrm{~W}$ \\
\hline 10 & Becca di Luseney & 8 June 1952 & 603630 & 79700 & $>10^{6}$ & 2950 & W \\
\hline 11 & Feegletscher & 7 July 1954 & 636000 & 105850 & $10^{5}-10^{6}$ & 2330 & SE \\
\hline 12 & Monte Rosa I & 1980 & 634120 & 87060 & $10^{5}-10^{6}$ & 3940 & $\mathrm{NE}$ \\
\hline 13 & Druesberg & March 1987 & 705750 & 206800 & $10^{3}-10^{4}$ & 2120 & W \\
\hline 14 & Val Pola & 28 July 1987 & 822620 & 140300 & $>10^{6}$ & 2160 & $\mathrm{E}$ \\
\hline 15 & Piz Scerscen & autumn 1988 & 789520 & 139120 & $10^{4}-10^{5}$ & 3620 & SE \\
\hline 16 & Tschierva & 29 October 1988 & 788900 & 141650 & $10^{5}-10^{6}$ & 3220 & $\mathrm{~W}$ \\
\hline 17 & Combin de Grafeneire & - & 589950 & 86750 & $10^{4}-10^{5}$ & 3610 & SE \\
\hline 18 & Gugla & - & 630960 & 109100 & $10^{4}-10^{5}$ & 3230 & NE \\
\hline 19 & Jungfraujoch & 1991 & 641930 & 155220 & $10^{4}-10^{5}$ & 3460 & SE \\
\hline 20 & Randa & 18 April, 19 May 1991 & 625970 & 106910 & $>10^{6}$ & 2070 & SE \\
\hline 21 & Miage II & Mai/June 1991 & 554350 & 72100 & $10^{5}-10^{6}$ & 3000 & NW \\
\hline 22 & Zuetribistock & 24 January/03 March 1996 & 715180 & 189950 & $>10^{6}$ & 2110 & SE \\
\hline 23 & Drus II & 17 September 1997 & 562360 & 868780 & $10^{4}-10^{5}$ & 3300 & W \\
\hline 24 & Brenva II & 18 January 1997 & 556950 & 76140 & $>10^{6}$ & 3700 & $\mathrm{E}$ \\
\hline 25 & Mont Collon & - & 604800 & 92450 & $10^{4}-10^{5}$ & 2850 & $\mathrm{~N}$ \\
\hline 26 & Maettenberg & 08 September 2000 & 649080 & 161330 & $10^{5}-10^{6}$ & 2600 & NW \\
\hline 27 & Gruben & July/August 2002 & 642600 & 112700 & $10^{4}-10^{5}$ & 3460 & NW \\
\hline 28 & Drus III & 2 August 2003 & 562370 & 86880 & $10^{3}-10^{4}$ & 3400 & W \\
\hline 29 & Trubinasca & July 2003 & 764771 & 129516 & $10^{3}-10^{4}$ & 2840 & NE \\
\hline 30 & Chalchagn & summer 2003 & 788910 & 149430 & $10^{3}-10^{4}$ & 2460 & W \\
\hline 31 & Cengalo & July/August 2003 & 766700 & 129800 & $10^{3}-10^{4}$ & 2790 & $\mathrm{NE}$ \\
\hline 32 & Monte Rosa II & July/August 2003 & 634000 & 87200 & $10^{3}-10^{4}$ & 3990 & SW \\
\hline 33 & Dent Blanche & summer 2003 & 612700 & 96900 & $10^{3}-10^{4}$ & 3480 & W \\
\hline 34 & Piz Balzet & summer 2003 & 771080 & 134390 & $10^{3}-10^{4}$ & 2580 & W \\
\hline 35 & Corn Boval & summer 2003 & 789860 & 143570 & $10^{3}-10^{4}$ & 3080 & W \\
\hline 36 & Matterhorn, Arete du Lion & summer 2003 & 616040 & 91230 & $10^{3}-10^{4}$ & 3810 & SW \\
\hline 37 & Hoernligrat & 15 July 2003 & 618000 & 92200 & $10^{3}-10^{4}$ & 3440 & SE \\
\hline 38 & Matterhorn, La Cheminee & August 2003 & 616250 & 91300 & $10^{3}-10^{4}$ & 3630 & $\mathrm{~S}$ \\
\hline 39 & Marco e Rosa & August 2003 & 790100 & 138780 & $10^{3}-10^{4}$ & 3520 & $\mathrm{~S}$ \\
\hline 40 & Mont Velan & 2 August 2003 & 584500 & 83500 & $10^{3}-10^{4}$ & 3200 & $\mathrm{NE}$ \\
\hline 41 & Jaegerhorn & 4 Augus 2003 & 634200 & 89400 & $10^{4}-10^{5}$ & 3580 & NE \\
\hline 42 & Walker Pfeiler & 7 August 2003 & 564840 & 80170 & - & 3600 & $\mathrm{~N}$ \\
\hline 43 & Aiguille du Midi & 7 August 2003 & 557180 & 80760 & $10^{3}-10^{4}$ & 3520 & $\mathrm{~W}$ \\
\hline 44 & Piz Vadret & 12 August 2003 & 793625 & 173925 & $10^{3}-10^{4}$ & 3130 & $\mathrm{~N}$ \\
\hline 45 & Gross Ruchen & 4 September 2004 & 701940 & 185300 & $10^{3}-10^{4}$ & 2940 & NW \\
\hline 46 & Thurwieser & 18 September 2004 & 837200 & 153800 & $>10^{6}$ & 3600 & SE \\
\hline 47 & Drus IV & 29 June 2005 & 562380 & 86880 & $10^{5}-10^{6}$ & 3450 & W \\
\hline 48 & Roc Noir & 2006 & 604200 & 92870 & $10^{3}-10^{4}$ & 2680 & $\mathrm{NE}$ \\
\hline 49 & Eiger & June/July 2006 & 647100 & 160950 & $10^{5}-10^{6}$ & 1610 & NE \\
\hline 50 & La Crasta & July 2006 & 787300 & 139880 & $10^{3}-10^{4}$ & 3220 & NW \\
\hline 51 & Dent du Midi & 29 October 2006 & 559900 & 112600 & $>10^{6}$ & 2860 & NW \\
\hline 52 & Dents Blanches & 8 November 2006 & 553130 & 109230 & $>10^{6}$ & 2560 & $\mathrm{~N}$ \\
\hline 53 & Kleiner Spannort II & 2007 & 682300 & 181640 & $10^{4}-10^{5}$ & 3100 & $\mathrm{~N}$ \\
\hline 54 & Monte Rosa III & 21 April 2007 & 634080 & 86840 & $10^{5}-10^{6}$ & 4200 & NE \\
\hline 55 & Saentis & 22 May 2007 & 742700 & 234750 & $10^{3}-10^{4}$ & 2100 & $\mathrm{~N}$ \\
\hline 56 & Kärpf & 29 September 2007 & 725740 & 197450 & $10^{4}-10^{5}$ & 2670 & NW \\
\hline
\end{tabular}




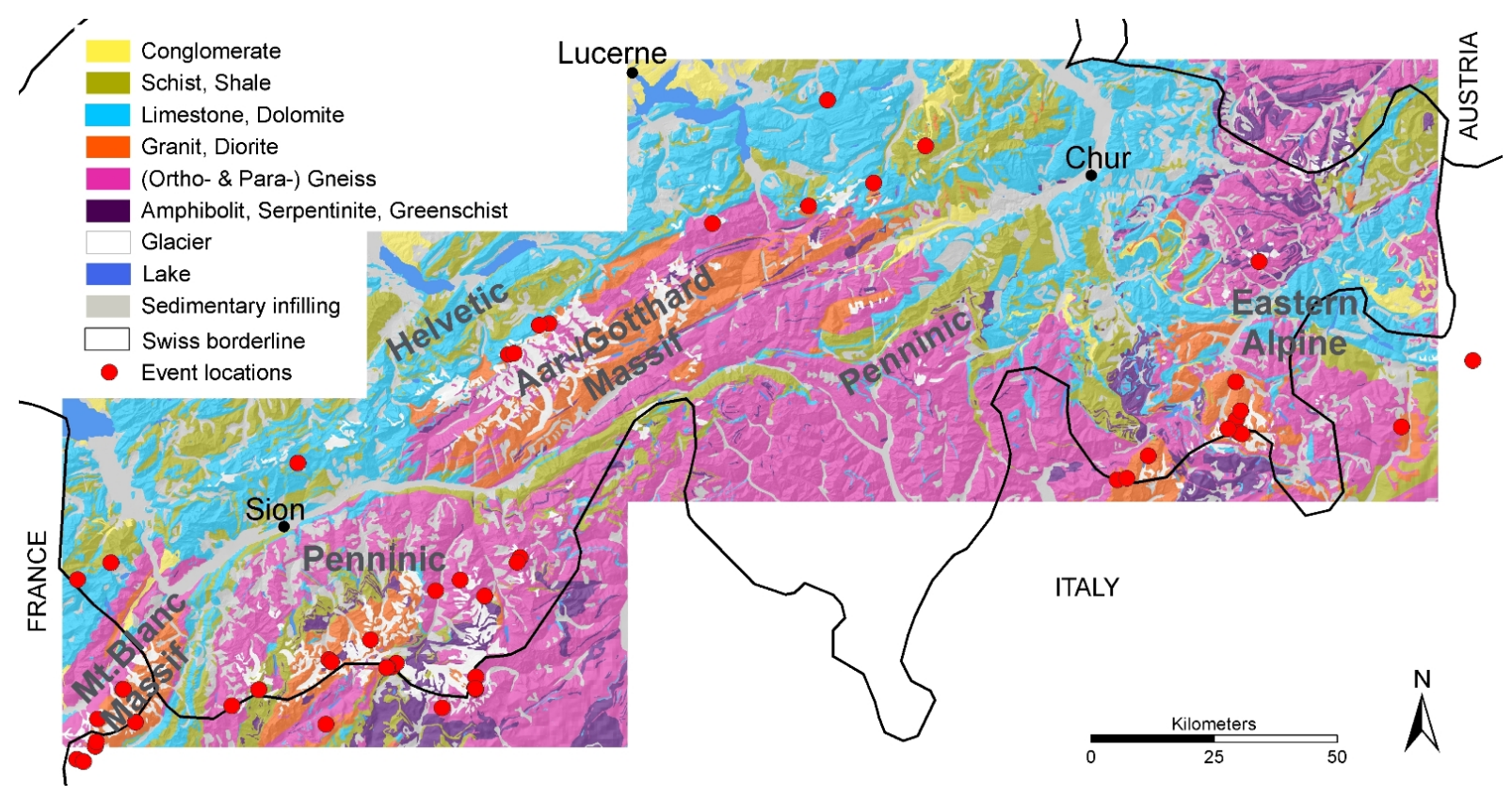

Fig. 3. Simplified geological classification of the Central Alps derived from the Geotechnical Environmental Atlas of Switzerland V1/00 ( ${ }^{()}$Swiss Geotechnical Commission; Geological basis data ${ }^{\complement}$ Swiss Federal Office of Topography, Section Geological Survey). Additionally, the main tectonic units are indicated. The class conglomerate contains sandstone, marl, breccias; schist/shale contains schist, shale, argillite, and similar lithologies; limestone/dolomite contains limestone and dolomite; granite/diorite contains mainly granitic lithologies and gabbro; gneiss contains both orthogneiss and paragneiss; amphibolite contains amphibolite, peridotite, serpentinite, greenschist (also called mafic metamorphic).

and glacier cover strongly increases with elevation from a few percents between 2000 and $2600 \mathrm{~m}$ a.s.l. to around $20 \%$ at $3000 \mathrm{~m}$. Above $3000 \mathrm{~m}$ a.s.1. $35-40 \%$ of the area is covered by glaciers.

Permafrost is present over large areas in the higher parts of the European Alps. Its lower limit of occurrence can be roughly estimated by using elevation and aspect as proxies for air temperature and direct solar radiation (Haeberli, 1975). On NE, N-, NW-and W-facing steep bedrock slopes discontinuous permafrost can occur from about $2500 \mathrm{~m}$ a.s.l., whereas the boundary on south-facing slopes lies around $3500 \mathrm{~m}$ a.s.l. (Gruber et al., 2004; Hasler et al., 2011). The vertical difference of up to $1000 \mathrm{~m}$ is mainly a result of the dominating influence of direct solar radiation. However, permafrost distribution in steep topography is very inhomogeneous and this basic pattern is overprinted by local topography, surface cover and subsurface material. During the past century, subsurface temperatures have likely increased as a result of atmospheric warming (Harris et al., 2009). However, monitoring of subsurface temperatures in steep bedrock permafrost has only been initiated in the last decade and no long time series exist (Deline et al., 2009; PERMOS 2010; Noetzli et al., 2010).

The study area consists of distinct climate regions, with the Alps introducing strong variations in climate by separating the north, strongly influenced by Atlantic climate, and the south, influenced by the Mediterranean. Furthermore, valleys in the central Alps have their own distinct climate, since they are shielded from precipitation from both the north and the south, leading to dry conditions. Along the northern Prealps and Alps, as well as in Southern Switzerland, average precipitation is about $2000 \mathrm{~mm} \mathrm{yr}^{-1}$, contrasting with the Valais region (between 500 and $600 \mathrm{~mm} \mathrm{yr}^{-1}$ ) and the Engadin region (between 600 and $700 \mathrm{~mm} \mathrm{yr}^{-1}$ ). The temperatures in the Alps primarily depend on the altitude, varying from mean yearly temperatures of $12^{\circ} \mathrm{C}$ in the lowland areas to $-10^{\circ} \mathrm{C}$ in the highest mountain regions (http://www.meteoschweiz.admin.ch/web/ en/climate/swiss_climate.html).

The Central Alps exhibit a medium earthquake hazard compared to the European average. This means that while strong earthquakes are rare, they can still occur (http://www. seismo.ethz.ch/eq_swiss/eq_ch/index_EN). However, for our historic database we assume that seismic triggers are unlikely for most of the events.

\section{Results: rock avalanche and rockfall distribution}

\subsection{Temporal distribution}

The catalogued periglacial rock avalanche and rockfall events are not equally distributed in time (Fig. 4). Since 


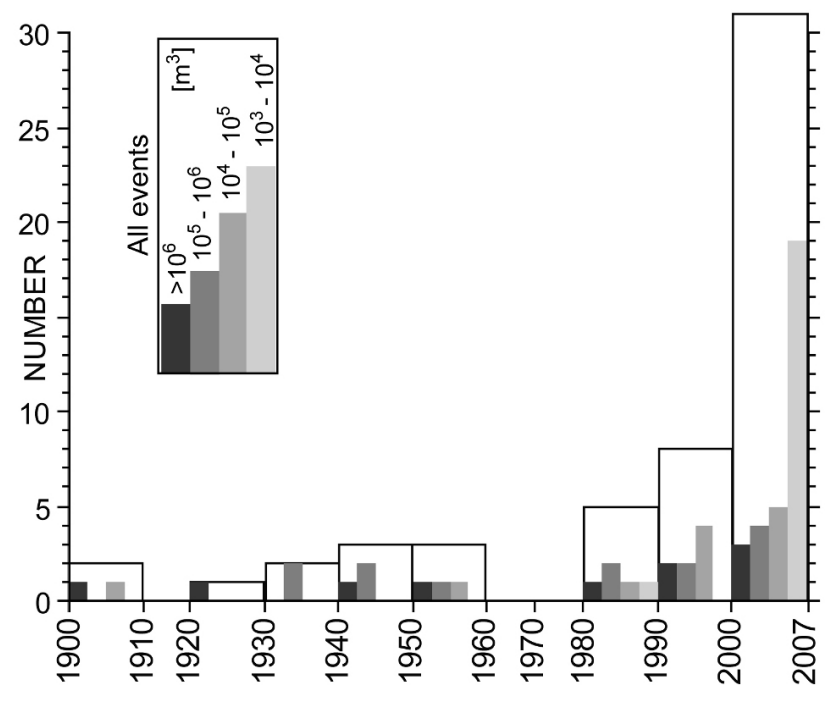

Fig. 4. Number of slope failure records per decade, divided into four volume classes. The increased number in the past three decades has to be considered with caution especially for the small-volume events because of the increased recording activities during this period.

1980 and especially between 2000 and 2007, more events were recorded than previously. It is difficult to separate this increase from the increased recording activity and thus observations as a result of increasing development in mountainous areas. This in turn makes it difficult to assess possible increases resulting from climate change and related changes in periglacial terrain. Nonetheless, we consider that the documentation of large-volume events is likely to be more or less complete over the whole investigation period. The records show an increased number of events with volumes $>100000 \mathrm{~m}^{3}$ between 1930 and 1950 and an even stronger increase in recent decades.

A closer look at the seasonal distribution shows that slope failure activity from steep bedrock walls varies in seasonal timing for different magnitudes (Fig. 5). Four different volumetric classes were considered, as the failure mechanism and processes involved in slope failures are assumed to differ between volume classes. Most of the recorded events could be allocated to one of the four volume classes. The smallest volumetric class $\left(1000 \mathrm{~m}^{3}-10000 \mathrm{~m}^{3}\right)$ contains 20 slope failures. 12 rock avalanche events had volumes between $10^{4}$ and $10^{5} \mathrm{~m}^{3}, 12$ events between $10^{5}$ and $10^{6}$ and 11 events were recorded with volumes $>10^{6} \mathrm{~m}^{3}$. In the smallest volume class, a clear peak in events during the summer season is observed (Fig. 5). A large number of these events occurred during the hot summer of 2003. In the three larger volume classes, no dominant seasonal pattern can be observed and the temporal distribution is more or less homogenous. An interesting observation is that very few recorded events occurred in winter.

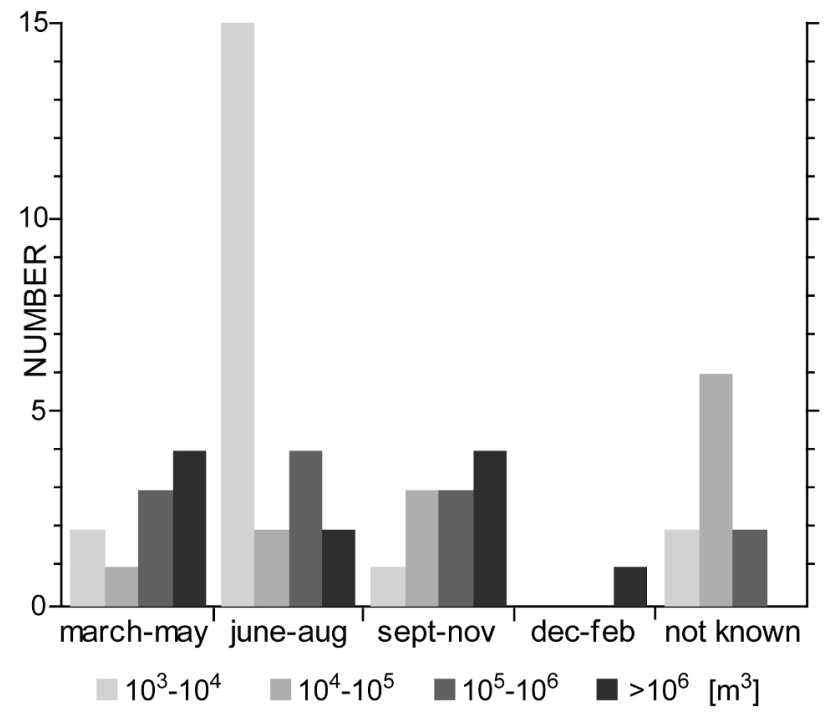

Fig. 5. Seasonal distribution of the slope failure events, divided into the four volume classes.

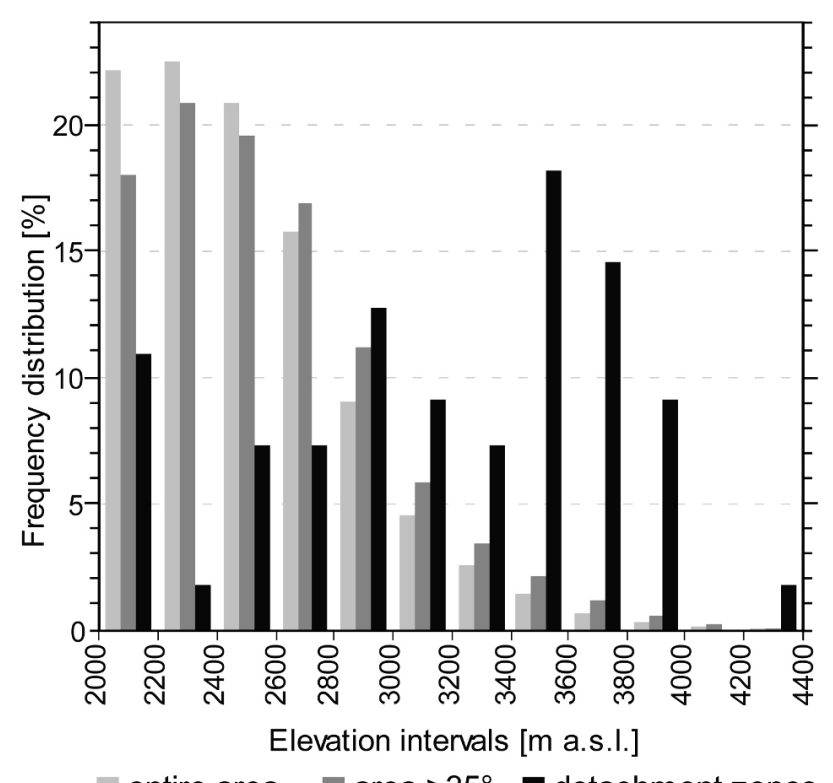

Fig. 6. Area distribution above $2000 \mathrm{~m}$ a.s.l. with respect to elevation over the entire area including glaciers, areas with slope angle $>35^{\circ}$, which are considered as bedrock areas and detachment zones, calculated in $200 \mathrm{~m}$ elevation increments.

\subsection{Topography}

As this study focuses on periglacial rock slope failures, our analyses are concentrated on areas above $2000 \mathrm{~m}$ a.s.l. (Fig. 2). Figure 6 shows the hypsometry of both the entire area above $2000 \mathrm{~m}$ a.s.l. (including bedrock, debris and glacier covered areas) and areas with gradient steeper than $35^{\circ}$, assuming this angle as a threshold for the distinction 

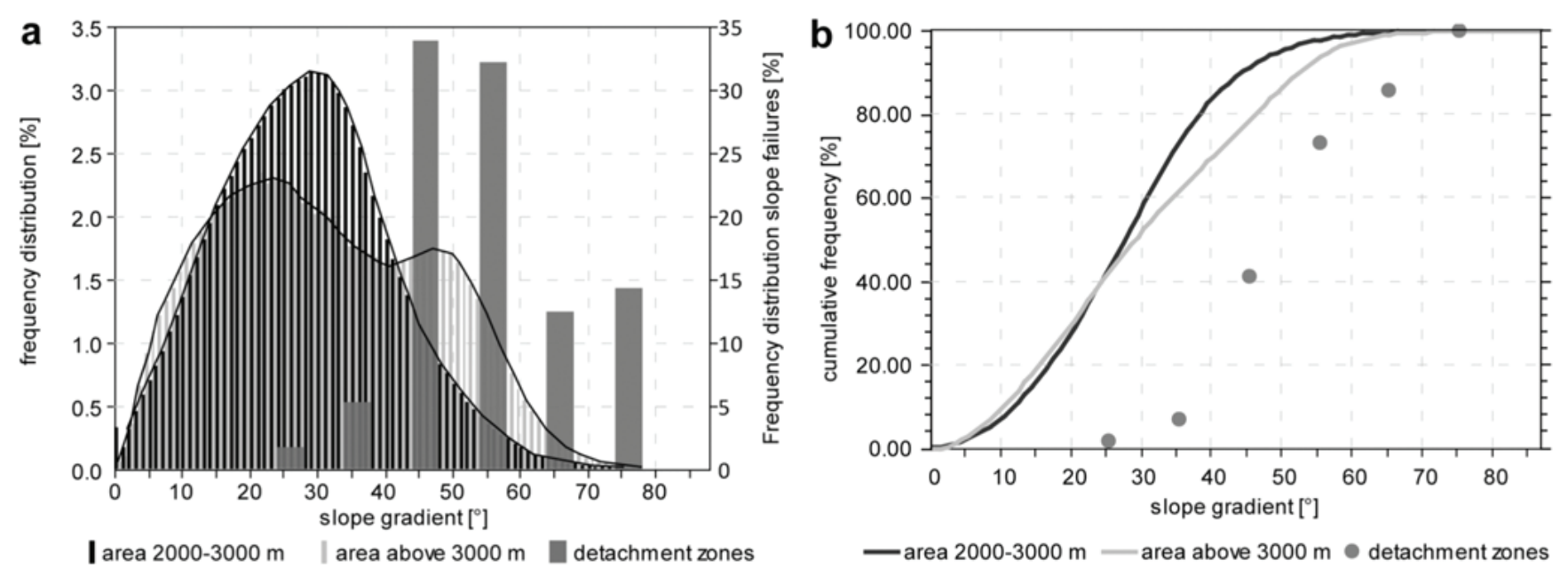

Fig. 7. Frequency distribution of slope gradients for the areas between 2000 and $3000 \mathrm{~m}$, the area above $3000 \mathrm{~m}$ a.s.1., and the slope failure detachment zones (in $10^{\circ}$ intervals; (a) and cumulative frequency of slope gradients for the same data sets (b).
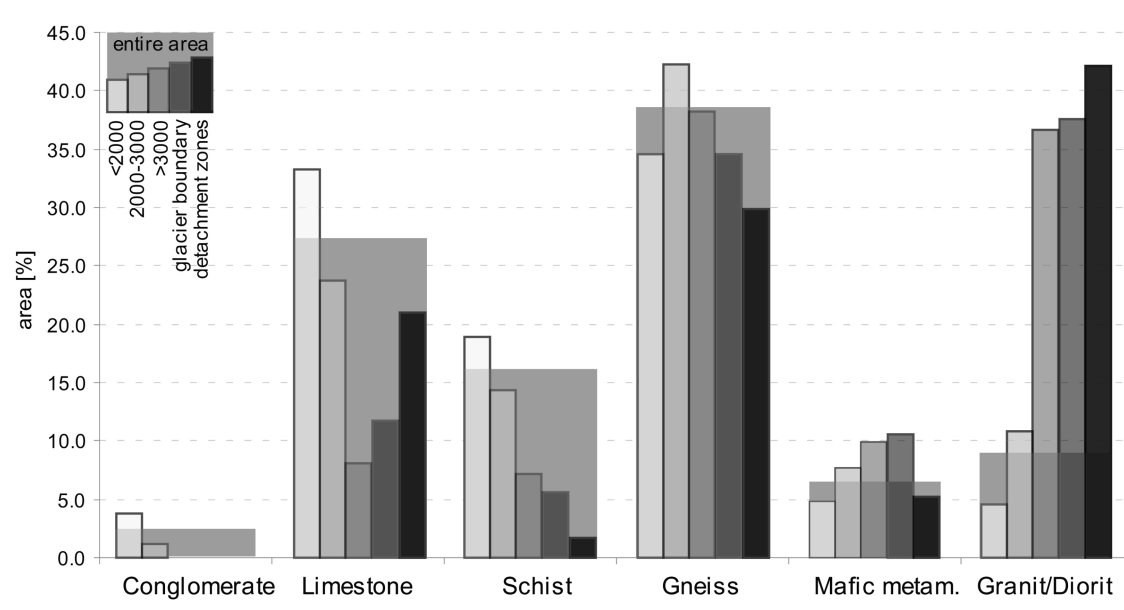

Fig. 8. Area proportion of the different lithological groups in different altitudinal belts, the lithological distribution along the glacier boundaries, and the lithological setting of the recorded slope failures (black).

of bedrock slopes (Zemp et al., 2005). The hypsometry of bedrock areas shows a slight shift towards higher elevations relative to the one of the entire investigation area, reflecting the fact that with increasing altitude the percentage of bare bedrock increases. Looking at the distribution of the detachment zones of the events, the shift towards higher elevations becomes more pronounced. Only $40 \%$ of the slope failures (i.e. 22 events) occurred between 2000 and $3000 \mathrm{~m}$ a.s.l., although $90 \%$ of the investigation area lies in this altitudinal belt. By contrast, $60 \%$ of the events ( 33 events) started above $3000 \mathrm{~m}$ a.s.l. (i.e. $10 \%$ of the entire investigation area).

As a fundamental driver of slope instability, slope gradient is typically incorporated into bedrock failure analyses. Figure 7 shows the distribution of slope gradient against area for different altitudinal belts and the detachment zones of the rock avalanche and rockfall events. The slope gradient distribution for the area between 2000 and $3000 \mathrm{~m}$ a.s.l. shows a normal distribution with the mode at ca. $30^{\circ}$ (Fig. 7a). The slope gradient frequency distribution for areas above $3000 \mathrm{~m}$, however, shows a different pattern: Two modes exist at ca. $20^{\circ}$ and $47^{\circ}$ and the terrain tends to be either flatter or steeper than between 2000 and $3000 \mathrm{~m}$. This can be explained by the occurrence of relatively flat glacier-covered areas and steep bedrock areas. The detachment zones show high slope gradients (Fig. 7), whereby the slope value is based on a single mean slope value within the detachment zone. The highest percentage of detachment zones shows slope values between $40-60^{\circ}$. Higher values than $60^{\circ}$ occur and slope gradient values below $40^{\circ}$ are rare. The cumulative frequency distribution of slope gradients at the detachment zones is about $20^{\circ}$ higher than for all land in the investigation area (Fig. 7b). 


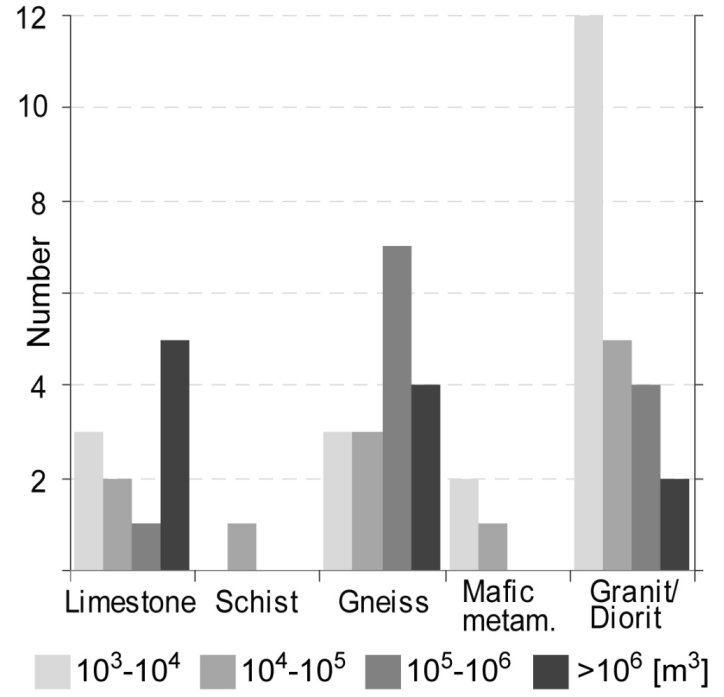

Fig. 9. Number of events of a particular volume class within the different lithologies.

\subsection{Geology}

The area-wide analysis shows that the different lithologies do not occur with equal frequency and are not equally distributed within the investigation area (Fig. 3) and over the different altitudinal belts (Fig. 8). Overall, gneiss (lithological classes are written in italics) covers the largest proportion of the investigation area (around $40 \%$ ), followed by limestone $(\sim 25 \%)$ and schist $(\sim 15 \%)$. The proportion of all other lithology classes is below $10 \%$ each. More detailed results considering the altitudinal distribution of the different lithological classes show that they are not equally distributed over altitude. Conglomerates do not exist above $3000 \mathrm{~m}$ a.s.l. and the proportion of limestone and schist significantly decreases (by $75 \%$, resp. $66 \%$ ) from below 2000 to above $3000 \mathrm{~m}$ a.s.l. (Fig. 8). By contrast, the proportion of the lithologies granite, gneiss and mafic metamorphic increases with elevation. Above $3000 \mathrm{~m}$ a.s.l. gneiss and granite are the predominant lithology. The distribution of the lithological setting at the detachment zones follows the overall lithological proportions with most detachment zones being located in gneiss followed by granite, limestone and mafic metamorphic (Fig. 8). However, considering the lithological proportions in the different altitudinal belts, proportionally more events are registered in limestone and granite and proportionally less in gneiss and mafic metamorphic.

It is important to note that the simplification of lithological classes required for a statistical analysis is a strong generalisation, which may induce errors, since similar lithologies can have very different geotechnical and geomechanical characteristics. Thus, for example, the gneiss class consists of a broad variation of gneiss-types, including both orthoand paragneiss, with strongly varying metamorphosis grade.
In a next step, the lithological setting and the slope failure volume are compared (Fig. 9). The two smaller volumeclasses are distributed over all lithologies with a very dominant maximal count in granite. Overall, the lithological classes granite and mafic metamorphic have a large number of small volume events and few events with very large volumes. The classes limestone and gneiss, by contrast, have more events in the large-volume classes. The largest slope failures predominantly occurred in limestone and to a lesser degree in gneiss. The lithology group schist is related to very few slope failures and none are recorded in conglomerate. This is probably influenced by the marginal portion of these lithologies within our investigation area, but also because they tend to be more prone to other types of mass movements, e.g. slow-moving, deep-seated, rotational landslides or continuous small-volume erosion.

\subsection{Glaciation}

Large areas of alpine rock walls are influenced by recent changes in glaciation as since the LIA, approximately half of the glacial cover has disappeared in the European Alps (Zemp et al., 2006). This glacier retreat was proportionally greatest between 1500 and $3000 \mathrm{~m}$ a.s.l. but is also documented above $3000 \mathrm{~m}$ a.s.l. Each detachment zone was classified for its glacierization state at the time of failure based on digital glacier inventories for 1850, 1973 and 1998. No glacierization means that there was neither surface ice in the flank nor at the foot of the rockwall since and during the LIA, implying that the last glacial influence was likely before the Holocene. 31 of the investigated detachment zones (corresponding to $56 \%$ ) showed no glacierization in their direct vicinitiy and are considered to have no recent glacial influence (Fig. 10a). 24 detachment zones (44\%) showed glacierization in their direct vicinity at failure time. This group with glacial influence has either a valley glacier directly at the foot of the particular rockwall or glacier ice within the flank. Here, the stress and thermal field in the flank is considered to be influenced by glacier retreat since the LIA.

Including the geological setting in the glacierization state analysis, we can see that for the lithologies limestone and granite, the number of events without glacier influence exceeds by far those with direct glacier presence (Fig. 10a). In the gneiss group, on the other hand, the number of events with glacier influence clearly exceeds those without glacier influence. To explore whether this is correlated to an area-wide higher proportion of gneiss around the glaciers than granite and limestone, the frequency distribution of the lithologies in the vicinity of glaciers was calculated in a $100 \mathrm{~m}$ boundary zone around all glaciers. The frequency distribution of the lithologies along the glacier boundaries corresponds well with their area-wide distribution (Fig. 8), with a proportionally even larger area of granite along glaciers. A normalization of the proportion of detachment zones with glacier presence by the proportion of the 


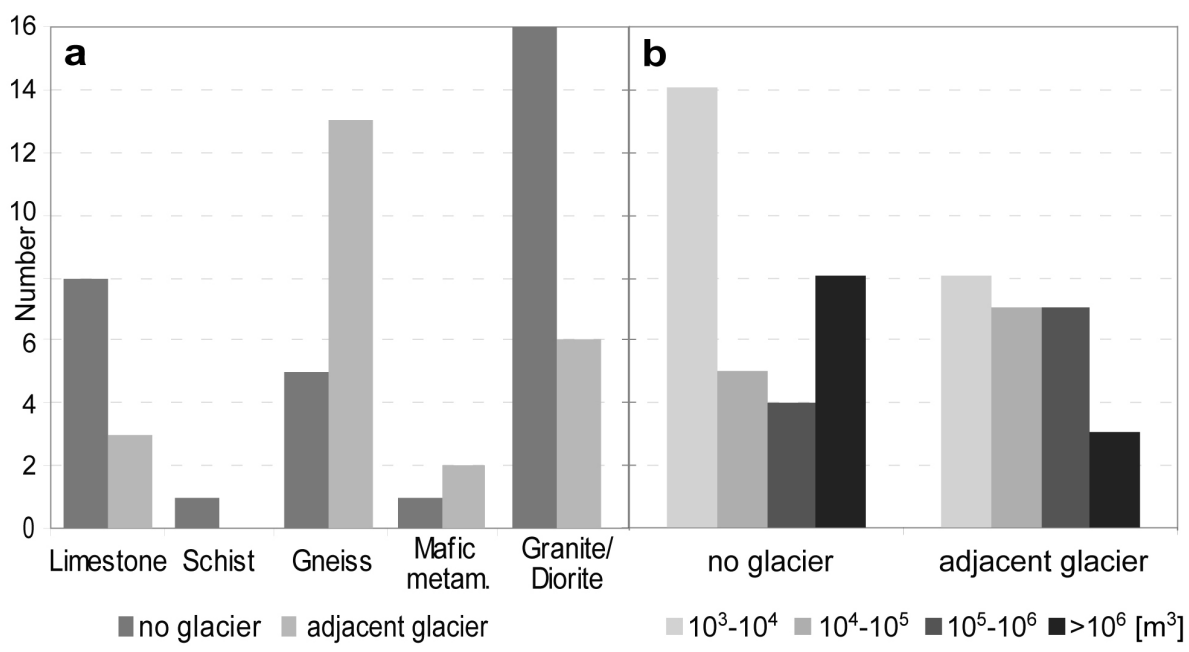

Fig. 10. (a) Glacierization situation at failure time of each rock avalanche event against the lithological classes. (b) glacierization state for the four volumetric classes.

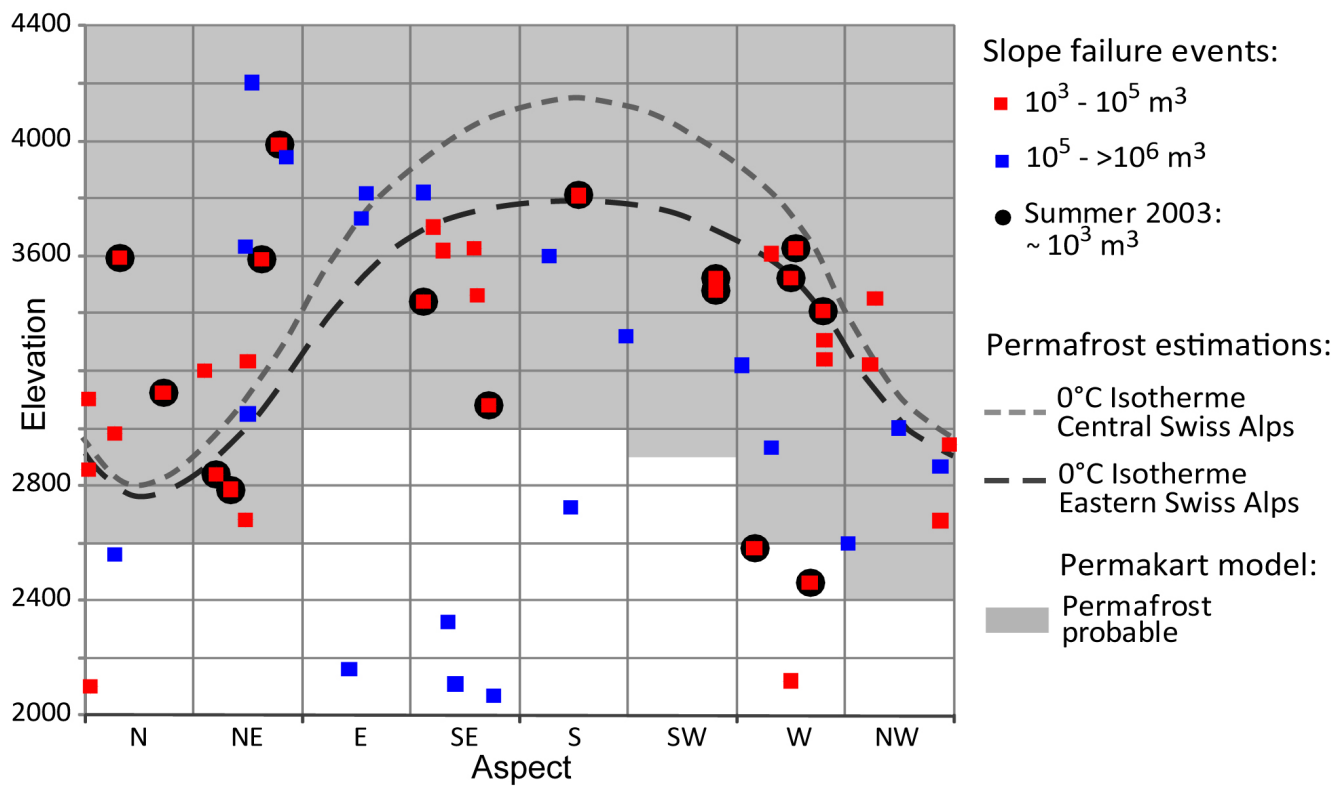

Fig. 11. The altitude of the detachment zones related to slope aspect as a first-order information about the permafrost setting, in relation to the assumed lower permafrost boundaries based on two approaches (adapted from Keller, 1992 and Gruber et al., 2004).

glacier boundary lithologies confirms that slope failures in gneiss detach more often in the vicinity of glaciers while events in granite lithologies detach less often than overall area proportion in the vicinity of glacier.

Figure $10 \mathrm{~b}$ depicts the glacierization state of the detachment zones for the four volumetric classes. The number of glacially influenced detachment zones is only half of those without recent glacierization in the smallest and largest volumetric classes. In the two intermediary classes, the pattern is inverted: the number of glacially influenced detachment zones is twice as high than without recent glacierization.

\subsection{Permafrost}

Rough estimations of permafrost occurrence at each reported detachment zone were made based on two basic permafrost model concepts. Figure 11 indicates probable permafrost occurrence based on the so-called "rules of thumb" by Haeberli (1975) implemented in the PERMAKART model (Keller, 1992) and two modelled $0{ }^{\circ} \mathrm{C}$-isotherms of nearsurface temperatures in steep rock based on meteo data from the Corvatsch and Jungfraujoch stations (Gruber et al., 2004; location of stations in Fig. 2). The difference in the displayed 
permafrost boundaries results from the different settings of the two approaches. PERMAKART was calibrated for rock glacier areas in the Upper Engadine and generally overestimates permafrost occurrence in steep bedrock, whereas the modelled $0^{\circ} \mathrm{C}$-isotherm ist most likely too high and thus underestimates permafrost extent in steep rock walls. The combination of the two, however, can be regarded as rough estimates of the lowest (PERMAKART) and uppermost $\left(0^{\circ} \mathrm{C}-\right.$ isotherm) possible altitude of the lower permafrost boundary.

For each detachment zone, altitude is plotted against aspect in Fig. 11. The slope failures are divided into two volumetric groups. Furthermore, the small-volume events from the exceptionally hot summer 2003 are indicated. The detachment zones are distributed more or less evenly across slopes of all aspects. However, when aspect is analysed together with elevation, the distribution of the detachment zones roughly follows the estimated permafrost boundary, especially for the small-volume group (Fig. 11). Thus, detachment zone altitudes on NW to NE aspects are typically located at lower altitudes, while those on E to SW are at higher altitudes, and the distribution follows roughly the shape of the plotted permafrost boundaries. This might indicate thermal conditions consistent with relatively warm permafrost for many of theses events. Large volume events, however, generally detached at lower altitudes than the small volume events, except for 6 events with slope expositions $\mathrm{NE}$ and $\mathrm{E}$. In general, small-volume events tend to release in areas around the modelled lower permafrost boundaries, whereas large-volume events show no obvious pattern with respect to the permafrost boundaries.

\section{Discussion}

\subsection{Temporal distribution}

In interpreting the results, it is important to consider the number of events documented and the sampling technique. We cannot draw conclusions about increases in rock fall events based on the existing inventory because recording activity has also increased during the past decades due to both increased human use of high mountain areas and higher public awareness of changing conditions in the Alps. This is likely to induce a bias in statements about the frequency of rock avalanche and rockfall occurrences. In particular, small-volume events of up to $10000 \mathrm{~m}^{3}$ without direct impact on people or infrastructure were rarely documented before about the year 2000 for high-mountain areas. However, we assume that the documentation of large-volume events $\left(10^{5}\right.$ to $\left.>10^{6} \mathrm{~m}^{3}\right)$ is more or less complete over the whole investigation time, since events of such large volumes are very unlikely to be unrecorded. 13 large-volume events have been documented during the past thirty years. By contrast, only 8 from the same volume class events were recorded between 1900 and 1980. Gruner (2006) stated that since the last Ice
Age, major rock avalanches with volumes $>1 \times 10^{6} \mathrm{~m}^{3}$ occur on average every 5 to $10 \mathrm{yr}$. Based on our results, the number of large-volume rock avalanches appears to have increased in frequency in recent decades.

An interesting pattern in slope failure occurrences can be observed between 1900 and 1980. Between 1910 and 1930 and again between 1960 and 1980, one and zero event respectively were recorded over $20 \mathrm{yr}$, whereas between 1930 and 1960, eight events were recorded within $30 \mathrm{yr}$. The two time periods with few events correspond to time periods without pronounced atmospheric warming or even slight cooling and glacier mass gain, whereas the time intervals with increasing numbers of recorded events coincide with times of strong atmospheric warming with strong cumulative glacier mass loss and rapid shrinking of surface ice (Huss et al., 2009). Although the number of events does not allow us to draw firm conclusions from the data presented here, this pattern could indicate increased activity of slope failures during times of rising temperatures and rapid glacier retreat, as also assumed for the recent increase of large slope failures since about 1980. Similar temporal patterns were found in a rockfall study in the Mont Blanc massif by Ravanel and Deline (2010), with increased slope failure records between 1940 and 1960 and again from 1990. Nevertheless, for largevolume as well as small-volume events, the inventory period and data set must be extended to allow for more reliable conclusions about frequency and magnitude trends.

\subsection{Topographic factors}

The detachment zone mapping shows that most of the events released from steep slopes and only $7 \%$ of the detachment zones had mean slope angles below $40^{\circ}$, based on an analyse with a $25 \mathrm{~m}$ DEM. The overall distribution of slope gradients in detachment zones is shifted by about $15-20^{\circ}$ towards steeper gradients compared to the area-wide slope gradients. Other studies have shown similar values for detachment zone slope angles, such as the higher proportion of rock avalanches observed from slopes steeper than $45^{\circ}$ by Allen et al. (2011). We suggest therefore that a slope angle of $40-45^{\circ}$ could be taken as a first rough threshold for the critical slope gradient for rock avalanches in future regional susceptibility analyses.

The concentration of detachment zones at higher elevations is postulated to be a result of a combination of factors. $60 \%$ of the slope failures originated from above $3000 \mathrm{~m}$ a.s.l. (i.e. $10 \%$ of the entire investigation area). This increased proportion of detachment zones above $3000 \mathrm{~m}$ a.s.l. can one hand be related to a significant increase of the average slope gradient in this zone (Fig. 7; Kühni and Pfiffner, 2001) and on the other hand be a result of the influence of periglacial weathering and recent changes in glacierization and permafrost. A large proportion of detachment zone slope gradients coincide with the second mode of the area-wide slope gradients over $3000 \mathrm{~m}$ and another $25 \%$ are located in even 
steeper terrain (Fig. 7a). Glacier coverage is more extensive in this altitudinal belt and as are the relative areas affected by recent glacier retreat. In the altitudinal belt 2000-3000 ma.s.l., for 6 out of 21 detachment zones $(29 \%)$ a glacier existed immediately below the failure, above $3000 \mathrm{~m}$ a.s.l., 18 of 33 detachment zones $(55 \%)$ had adjacent glacier cover. Several slope failures can be directly linked to recent glacier retreat, e.g. the Eiger rock slide (Oppikofer et al., 2008) and a rock avalanche from the Monte Rosa east face in 2007 (Fischer et al., 2011).

\subsection{The influence of geology and glacierization in relation to the volume classes}

As the percentage of lithologies within the detachment zones corresponds well with their area-wide percentage, we assume a weak relation between slope failure and general geology. However, the lithological setting tends to have a strong influence on the volume of the slope failures. The classes granite and amphibolite produce smaller volumes, whereas gneiss and limestone produce both small and large volumes events. Such dependencies were already observed by Abele (1974). We can also state, that glacier retreat tends to cause more slope failures in gneiss lithologies than in the granite and limestone classes. This apparent relationship could be explained by varying reactions of different rock types with specific rock mass properties and structural settings to glacier retreat and redistribution of internal rock stresses. Augustinus (1997) suggests, based on studies in the New Zealand Southern Alps, that the rock mass strength (RMS) of eroded and debutressed rock mass is a major control on slope stability.

Almost half of the slope failure events occurred in areas with recent changes in glacierization, where recent means since the LIA. Our investigations show that changes in glacier cover do not affect all volumetric classes in the same way. The smallest $\left(<10000 \mathrm{~m}^{3}\right)$ and largest volumetric groups $\left(>1 \times 10^{6} \mathrm{~m}^{3}\right)$ occur predominantly in areas without recent glacier influence. Large events are thought to be more influenced by long-term effects of the retreat of the LGM glaciers, such as the Randa (Eberhardt et al., 2004) or the Tschierva rock avalanche (Fischer et al., 2010).

The smallest volumetric group shows many events in areas without glacierization. As most of these events are located in areas with probable permafrost occurrence (Fig. 11), they are probably more influenced by changes in the thermal regime and active layer thickness. However, the intermediate volume classes often seem to be influenced or predisposed by glacier retreat. Cruden and $\mathrm{Hu}$ (1993, cf. Ballantine, 2002) proposed an exhaustion model of temporal distribution of rock slope failures, which suggests that the number of failures exponentially decreases with time following deglaciation. The accelerated and irreversible atmospheric warming predicted for the coming century (IPCC, 2007) will enhance down wasting of valley glaciers and the loss of steep ice as well as permafrost warming, which will all probably negatively influence slope stability in the European Alps and similar mountain ranges. The area of bedrock slopes influenced by glacier retreat will increase and based on the assumptions of Cruden and $\mathrm{Hu}$ (1993), the number of slope failures as a short-term reaction to the changes in topography, stress and thermal fields could increase in the near future. However, the dimensions of the current glacier retreat are much smaller than that following the LGM and therefore the impact on the stress fields will be smaller, thus probably causing more medium-volume than large events.

\subsection{Permafrost}

Permafrost boundaries were estimated with basic methods suitable for a first assessment, and large uncertainties exist. However, the comparison of the location of the detachment zones (altitude-aspect) with two basic permafrost altitudinal boundary estimates reveals a concentration of the detachment zones in areas between the estimated maximum and minimum permafrost boundaries. The detachment zones also show the same pattern in elevation as the permafrost boundaries with higher locations in southern and lower locations in northern direction. The zone between the estimated maximum and minimum permafrost boundaries can be interpreted as the marginal permafrost zone, which is probably most prone to changes. This is in agreement with ideas of Davies et al. (2001) and Haeberli et al. (1997), that warming ice in rock discontinuities becomes less stable a few degrees below the melting point, where mixtures of rock, water, and ice exist. The marginal permafrost zones are thought to be the areas where most recent changes have taken place concerning ice content and hydrology, and thus have an enhanced influence on slope stability (Allen et al., 2011). However, before definitive conclusions can be made on the state, temperature and ice content of permafrost, there is a need for more geophysical measurements of such properties (e.g. Krautblatter and Hauck, 2007; Hasler et al., 2011).

The relatively small volumes of the slope failure events in the hot summer 2003 indicate changes in the near-surface. These events are most likely related to an extension of active layer thickness into previously ice-filled discontinuities (Gruber et al., 2004). The 2003 events do not show the same distinct accumulation around the modelled lower permafrost boundary as the other small-volume events but scatter over all altitudes and aspects. This might be due to the exceptional temperature conditions in this summer, affecting the active layer conditions irrespective of topographic setting. By contrast, the fact that several large-volume events occurred in autumn/winter (e.g. the Brenva rock avalanche in January 1997), points to processes and changes that take place at greater depths and develop over longer time periods, and hence could be related to long-term climatic and largescale topographic rather than to seasonal variations of surface temperatures. Ongoing atmospheric warming will increase 
the area and volume of bedrock subject to change in permafrost temperatures. Most especially, progressive thermal changes at larger depths in permafrost zones could influence the size of future slope failures and lead to increased rock avalanche volumes. An important process to consider may be the advective heat transfer processes that can penetrate much faster and may be particularly favoured by rock discontinuity systems (Huggel, 2009; Hasler, 2011). Therefore, more detailed investigations of the three-dimensional distribution and evolution of permafrost temperatures (Noetzli and Gruber, 2009), as well as field- and laboratory-based freezethaw and water content measurements, could help to improve process understanding (Hasler et al., 2011).

\section{Conclusions}

A rock avalanche and rockfall inventory provides an insight into the spatial and temporal distribution of slope failure events and provides a basis for the analysis of the empirical relationships between instabilities and local factors. In this study, slope failures are explored based on individual and combined factors such as topography, geology and the cryosphere.

From a statistical point of view, the number of rock avalanche and rockfall events in our inventory is low. Therefore, we have concentrated on a descriptive approach, comparing the characteristics of the detachment zones with their settings over the entire area. The separate investigation of the different factors allows us to draw the following conclusions:

- An increase in large-volume events during a time period characterised by global atmospheric temperature rise is observed. No final temporal conclusions are possible for small-volume events; however, they show a prominent seasonal pattern with most events in summer time.

- The detachment zones are not evenly distributed over elevation but the proportion strongly increases at elevations above $2800 \mathrm{~m}$ a.s.l. and even more above $3400 \mathrm{~m}$, which can be related to the increase of the average slope gradient in this zone and also might indicate the strong influence of peri-/paraglacial weathering on slope stability.

- Based on our results, a mean slope gradient threshold of $40-45^{\circ}$ is proposed as a rough lower threshold for rock slope failures in regional susceptibility analyses.

- Lithology influences the volume rather than the frequency of a slope failure. Granite is related to more small-volume events, whereas gneiss and limestone lithologies are associated with both large- and smallvolume events.

- Almost half of the rock avalanche and rockfall events occurred in areas affected by recent deglaciation, and especially the slope failures of the volumetric classes from $10000 \mathrm{~m}^{3}$ to $100000 \mathrm{~m}^{3}$ are found in areas with recent changes in glacierization.

- Many of the detachment zones are located in permafrost areas and a concentration along the lower permafrost boundary is observable for small-volume events.

Our analyses indicate several factors and factor combinations, which influence slope stability in high-mountain areas. However, care must be taken in drawing detailed conclusions on processes from this regional-scale analysis, since sample size is limited, the inventory is based on a short historical/observational record, the sample is likely to be incomplete for even the past century, and biased by larger events which are more likely to have been recorded, and detailed characteristics of the detachment zones are often not available, have changed over time, and are difficult to access and observe.

In future projects, increased bedrock failure susceptibility could be assessed descriptively by identifying areas where the critical factors are concentrated. Simple GIS-based spatial analyses with an additional rating of the individual factors can be used for such first-order susceptibility analyses and contribute to the detection of hot spots, where critical factor combinations occur. For more detailed analyses of events, climatic conditions in general and at the time of failure, structural controls and earthquake activity should be included as important factors for slope stability.

Acknowledgements. The authors thank B. Nägeli and H. Raetzo (Federal Office for the Environment, BAFU) for collaboration and information on slope failure events. Special thanks are due to P. Deline, an anonymous referee, and the editor T. Glade for careful and very constructive reviews. We acknowledge the support and funding from the Swiss National Science Foundation (project no. 200021-111967). The DHM25 is provided by swisstopo and the Geotechnical Environmental Atlas of Switzerland is provided by the Swiss Geotechnical Commission.

Edited by: T. Glade

Reviewed by: P. Deline and another anonymous referee

\section{References}

Abele, G.: Bergstürze in den Alpen; ihre Verbreitung, Morphologie und Folgeerscheinungen, Wissenschaftliche Alpenvereinshefte, 25, 230 pp., 1974.

Allen, S. K., Cox, S. C., and Owens, I. F.: Rock avalanches and other landslides in the central Southern Alps of New Zealand: a regional study considering possible climate change impacts, Landslides, 8, 33-48, doi:10.1007/s10346-010-0222-z, 2011.

Augustinus, P.: Rock mass strength and the stability of some glacial valley slopes, Z. Geomorph. N. F., 1, 55-68, 1995.

Baillifard, F., Jaboyedoff, M., and Sartori, M.: Rockfall hazard mapping along a mountainous road in Switzerland using a GISbased parameter rating approach, Nat. Hazards Earth Syst. Sci., 3, 435-442, doi:10.5194/nhess-3-435-2003, 2003. 
Ballantyne, C. K.: Paraglacial Geomorphology, Quarternary Sci. Rev., 21, 1935-2017, 2002.

Barla, G., Dutto, F., and Mortara, G.: Brenva Glacier rock avalanche of 18 January 1997 on the Mont Blanc range, northwest Italy, Landslide News, 13, 2-5, 2000.

Carrara, A. and Pike, R. J.: GIS technology and models for assessing landslide hazard and risk, Geomorphology, 94, 257-260, 2008.

Cola, G.: The large landslide of the south-east face of Thurwieser peak (Thurwieser-Spitze) $3658 \mathrm{~m}$ (Upper Valtellina, Italy), Terra Glacialis, 8, 38-45, 2005.

Crosta, G. B., Chen, H., and Lee, C. F.: Replay of the 1987 Val Pola Landslide, Italian Alps, Geomorphology, 60, 127-146, 2004.

Cruden, D. M. and Hu, X-Q.: Exhaustion and steady state models for predicting landslide hazards in the Canadian Rocky Mountains, Geomorphology, 8, 279-285, 1993.

Davies, M. C. R., Hamza, O., and Harris, C.: The effect of rise in mean annual temperature on the stability of rock slopes containing ice-filled discontinuities, Permafrost Periglac., 12, 137-144, 2001.

Densmore, A. L. and Hovius, N.: Topographic fingerprint of bedrock landslides, Geology, 28, 371-374, 2000.

Deline, P.: Recent Brenva rock avalanches (Valley of Aosta): New chapter in an old story?, Suppl. Geogr. Fis. Dinam. Quat. V, 5563, 2001.

Deline, P., Coviello, V., Cremonese, E., Gruber, S., Krautblatter, M., Jaillet, S., Malet, E., Morra di Celle, U., Noetzli, J., Pogliotti, P., Rabatel, A., Ravanel, L., Sadier, B., and Verleysdonk, S.: L'Aiguille du Midi (massif du Mont Blanc), un site remarquable pour l'étude du permafrost des parois d'altitude, Collection EDYTEM, Cahiers de Géographie, 8, 135-146, 2009.

Eberhardt, E., Stead, D., and Coggan, J. S.: Numerical analysis of initiation and progressive failure in natural rock slopes - the 1991 Randa rockslide, Int. J. Rock Mech. Min. Sci., 41, 69-87, 2004.

Eisbacher, G. H. and Clague, J. J., Destructive mass movements in high mountains: hazard and management, Geological Survey of Canada, Paper, 84-16, 1984.

Evans, S. G. and Clague, J. J.: Recent climatic change and catastrophic geomorphic processes in mountain environments, Geomorphology, 10, 107-128, 1994.

Evans, S. G., Scarascia-Mugnozza, G., Strom, A. L., Hermanns, R. L., Ischuk, A., and Vinnichenko, S.: Landslides from massive rock slope failure and associated phenomena, in: Landslides from massive rock slope failure, edited by: Evans, S. G., Scarascia-Mugnozza, G., Strom, A. L., and Hermanns, R. L., NATO Science Series IV, Springer, Dordrecht, 49, 3-52, 2006.

Fischer, L.: Slope Instabilities on Perennially Frozen and Glacierised Rock Walls: Multi-Scale Observations, Analyses and Modelling, Schriftenreihe Physische Geographie, Ph.D. thesis, University of Zurich, Switzerland, 58, 2009.

Fischer, L., Kääb, A., Huggel, C., and Noetzli, J.: Geology, glacier retreat and permafrost degradation as controlling factors of slope instabilities in a high-mountain rock wall: the Monte Rosa east face, Nat. Hazards Earth Syst. Sci., 6, 761-772, doi:10.5194/nhess-6-761-2006, 2006.

Fischer, L., Amann, F., Moore, J. R., and Huggel, C.: The 1988 Tschierva rock avalanche (Piz Morteratsch, Switzerland): An integrated approach to periglacial rock slope stability assessment, Eng. Geol., 116, 32-43, 2010.
Fischer, L., Eisenbeiss, H., Kääb, A., Huggel, C., and Haeberli, W.: Monitoring topographic changes in a periglacial high-mountain face using high-resolution DTMs, Monte Rosa east face, Italian Alps, Permafrost Periglac., 22, 140-152, doi:10.1002/ppp.717, 2011.

Fitzsimons, S. J. and Veit, H.: Geology and geomorphology of the European Alps and the Southern Alps of New Zealand: A comparison, Mt. Res. Dev., 21, 340-349, 2001.

Geertsema, M., Clague, J. J, Schwab, J. W., and Evans, S. G.: An overview of recent large catastrophic landslides in northern British Columbia, Canada, Eng. Geol., 83, 120-143, 2006.

Gruber, S.: Mountain permafrost: transient spatial modelling, model verification and the use of remote sensing, $\mathrm{Ph} . \mathrm{D}$. thesis, University of Zurich, Switzerland, 2005.

Gruber, S. and Haeberli, W.: Permafrost in steep bedrock and its temperature-related destabilization following climate change, J. Geophys. Res., 112, F02S18, doi:10.1029/2006JF000547, 2007.

Gruber, S., Hoelzle, M., and Haeberli, W.: Permafrost thaw and destabilization of Alpine rock walls in the hot summer of 2003, Geophys. Res. Lett., 31, L13504, doi:10.1029/2004GL020051, 2004.

Gruner, U.: Klima und Sturzereignisse in Vergangenheit und Zukunft, Bull. Angew. Geol., 9, 23-37, 2004.

Haeberli, W.: Untersuchungen zur Verbreitung von Permafrost zwischen Flüelapass und Piz Grialetsch (Graubünden), Mitteilungen der Versuchsanstalt für Wasserbau, Hydrologie und Glaziologie, 17, ETH Zürich, 1975.

Haeberli, W., Wegmann, M., and Vonder Mühll, D.: Slope stability problems related to glacier shrinkage and permafrost degradation in the Alps, Eclogae Geol. Helv., 90, 407-414, 1997.

Haeberli, W., Huggel, C., Kääb, A., Polkvoj, A., Zotikov I., and Osokin, N.: The Kolka-Karmadon rock/ice slide of 20 September 2002: An extraordinary event of historical dimensions in North Ossetia, Russian Caucasus, J. Glaciol., 50, 533-546, 2004.

Harris, C., Arenson, L. U., Christiansen, H. H., Etzelmüller, B., Frauenfelder, R., Gruber, S., Haeberli, W., Hauck, C., Hölzle, M., Humlum, O., Isaksen, K., Kääb, A., Kern-Lütschg, M. A., Lehning, M., Matsuoka, N., Murton, J. B., Nötzli, J., Phillips, M., Ross, N., Seppälä, M., Springman, S. M., and Vonder Mühll, D.: Permafrost and climate in Europe: Monitoring and modelling thermal, geomorphological and geotechnical responses, Earth Sci. Rev., 92, 117-171, 2009.

Hasler, A.: Thermal conditions and kinematics of steep bedrock permafrost, Ph.D. thesis, University of Zurich, Zurich, Switzerland, 164 pp., 2011.

Hasler, A., Gruber, S., and Haeberli, W.: Temperature variability and offset in steep alpine rock and ice faces, The Cryosphere, 5, 977-988, doi:10.5194/tc-5-977-2011, 2011.

Huggel, C.: Recent extreme slope failures in glacial environments: effects of thermal perturbation, Quaternary Sci. Rev., 28, 11191130, doi:10.1016/j.quascirev.2008.06.007, 2009.

Hungr, O., Evans, S. G., Bovis, M. J., and Hutchinson, J. N.: A review of the classification of landslides of the flow type, Environ. Eng. Geosci., 7, 221-238, 2001.

Huss, M., Funk, M., and Ohmura, A.: Strong Alpine glacier melt in the 1940s due to enhanced solar radiation, Geophys. Res. Lett., 36, L23501, doi:10.1029/2009GL040789, 2009.

IPCC: Climate Change 2007: The Physical Science Basis. Contribution of Working Group 1 to the Fourth Assessment Report 
of the Intergovernmental Panel on Climate Change, edited by: Solomon, S., Qin, D., Manning, M., Chen, Z., Marquis, M. C., Averyt, K., Tignor, M., and Miller, H. L., Intergovernmental Panel on Climate Change, Cambridge and New York, 2007.

Keller, F.: Automated mapping of permafrost using the program PERMAKART within the geographical information system ARC/INFO, Permafrost Periglac., 3, 133-138, 1992.

Keller, F.: Project report on rock fall 2003 to the Kanton Graubünden. Inst. Für Tourismus und Landschaft Acad. Engiadina, Samedan, Switzerland, 2003.

Keller, O. and Krayss, E.: Datenlage und Modell einer RheinLinth- Vorlandvergletscherung zwischen Eem-Interglazial und Hochwürm, in: Festschrift Wolfgang Schirmer, edited by: Ikinger, A., GeoArchaeoRhein, 2, 121-138, 1998.

Kneisel, C.: Permafrost in recently deglaciated glacier forefields measurements and observations in the eastern Swiss Alps and northern Sweden, Zeitschrift für Geomorphologie N.F., 47, 289305, 2003.

Korup, O., Schmidt, J., and McSaveney, M.: Regional relief characteristics and denundation pattern of the western Southern Alps, New Zealand, Geomorphology, 71, 402-423, 2005.

Krautblatter, M. and Hauck, C.: Electrical resistivity tomography monitoring of permafrost in solid rock walls, J. Geophys. Res., 112, F02S20, doi:10.1029/2006JF000546, 2007.

Kubat, E.: Felsinstabilitäten im Albignagebiet (Bergell): Ereigniskartierung und Analyse, MSc thesis, University of Zurich, Switzerland, 2007.

Kühni, A. and Pfiffner, O. A.: The relief of the Swiss Alps and adjacent areas and its relation to lithology and structure: Topographic analysis from a 250-m DEM, Geomorphology, 41, 285307, 2001.

Maisch, M.: Die Gletscher Graubündens, Rekonstruktion und Auswertung der Gletscher und deren Veränderungen seit dem Hochstand von 1850 im Gebiet der östlichen Schweizer Alpen (Bündnerland und angrenzende Regionen), Geographisches Institut der Universität Zürich, Physische Geographie, 33, Part A: 324 pp., Part B: 128 pp., 1992.

Meteoschweiz: availabe at: http://www.meteoschweiz.admin.ch/ web/en/climate/swiss_climate.html, last access date: 20 September 2011.

Montandon, F.: Chronologie des grand éboulements alpins, du début de l'ère chrétienne à nos jours, Société de Géography Genève, Matériaux pour l'étude des calamites, 32, 271-340, 1933.

Müller, F., Caflish, T., and Müller, G.: Firn und Eis der Schweizer Alpen, Gletscherinventar, Geographisches Institut, vdf-Verlag, ETH Zürich, 57, 174 pp., 1976.

Naegeli, B.: Felsstürze und Permafrost: Ereignisanalyse und Abschätzung der Permafrostverhältnisse von Anrisszonen in den Alpen, MSc thesis, University of Zurich, Switzerland, 2010.

Noetzli, J.: Felsstürze aus Permafrost über Gletscher - Ansätze zur GIS-basierten Modellierung, MSc thesis, University of Zurich, Switzerland, 2003.

Noetzli, J. and Gruber, S.: Transient thermal effects in Alpine permafrost, The Cryosphere, 3, 85-99, doi:10.5194/tc-3-85-2009, 2009.
Noetzli, J., Hoelzle, M., and Haeberli, W.: Mountain permafrost and recent Alpine rock-fall events: a GIS-based approach to determine critical factors, in: Proceedings of the 8th International Conference on Permafrost, Zurich, Switzerland, 2, 827832, 2003.

Noetzli, J., Gruber, S., and von Poschinger, A. : Modellierung und Messung von Permafrosttemperaturen im Gipfelgrat der Zugspitze, Deutschland, Geographica Helvetica, 2, 113-123, 2010.

Oppikofer, T., Jaboyedoff, M., and Keusen, H.-R.: Collapse at the eastern Eiger flank in the Swiss Alps, Nat. Geosci., 1, 531-535, 2008.

PERMOS: Permafrost in Switzerland 2006/2007 and 2007/2008, Glaciological Report (Permafrost) No. 8/9 of the Cryospheric Commission of the Swiss Academy of Sciences, edited by: Noetzli, J. and Vonder Muehll, D., 68 pp., 2010.

Ravanel, L.: Caractérisation, facteurs et dynamiques des écroulements rocheux dans les parois à permafrost du massif du Mont Blanc, Ph.D. thesis, University of Savoie, France, 2010.

Ravanel, L. and Deline, P.: Climate influence on rockfalls in highAlpine steep rockwalls: the north side of the Aiguilles de Chamonix (Mont Blanc massif) since the end of the Little Ice Age, Holocene, 21, 357-365, doi:10.1177/0959683610374887, 2010.

Paul, F.: The new Swiss glacier inventory 2000 - Application of remote sensing and GIS, Schriftenreihe Physische Geographie, Ph.D. thesis, University of Zurich, 52, 2004.

Ruff, M. and Czurda, K.: Landslide susceptibility analysis with a heuristic approach in the Eastern Alps (Vorarlberg, Austria), Geomorphology, 94, 314-324, 2008.

Seismo: available at: http://www.seismo.ethz.ch/eq_swiss/eq_ch/ index_EN, last access date: 20 September 2011.

Swisstopo: DHM25 - The digital height model of Switzerland, Product Information, available at: http://www.swisstopo.admin. ch/internet/swisstopo/en/home/products/height/dhm25.html (last access: 20 September 2011), 2004.

Tart, R. G.: Permafrost, in: Landslides: Investigation and Mitigation, edited by: Turner, A. K. and Schuster, R. L., Transportation Research Board National Research Council, Washington DC, USA, National Academy Press, Special Report 247, 620-645, 1996.

van Westen, C. J., Castellanos, E., and Kuriakose, S. L.: Spatial data for landslide susceptibility, hazard, and vulnerability assessment: An overview, Eng. Geol., 102, 112-131, 2008.

Wegmann, M., Gudmundsson, G. H., and Haeberli, W.: Permafrost changes in rock walls and the retreat of Alpine glaciers: a thermal modelling approach, Permafrost Periglac., 9, 23-33, 1998.

Zemp, M., Kääb, A., Hoelzle, M., and Haeberli, W.: GIS-based modelling of glacial sediment balance, Zeitschrift für Geomorphologie N. F., Suppl.-Vol. 138, 113-129, 2005.

Zemp, M., Paul, F., Hoelzle, M., and Haeberli, W.: Glacier fluctuations in the European Alps 1850-2000: an overview and spatiotemporal analysis of available data, in: The darkening peaks: Glacial retreat in scientific and social context, edited by: Orlove, B., Wiegandt, E., and Luckman, B., University of California Press, 152-167, 2006. 